\title{
Optic Nerve Sheath Diameter Measurement in Children Presenting to a Pediatric Emergency Department with Head Trauma
}

\author{
Acil Servise Kafa Travması ile Gelen Çocuklarda Optik Sinir Killı Çapı Ölçümü
}

\author{
(1) Sabiha Şahin1, (D) Kürşat Bora Carman², (D) Coşkun Yarar2 \\ 1 Eskişehir Osmangazi University Faculty of Medicine, Department of Pediatric Emergency, Eskişehir, Turkey \\ 2Eskişehir Osmangazi University Faculty of Medicine, Department of Pediatric Neurology, Eskişehir, Turkey
}

\section{Abstract}

Introduction: Optic nerve sheath diameter (ONSD) measurement is a non-invasive and easy imaging technique for the estimation of intracranial pressure in children and adults. We aimed to measure the ONSD in pediatric patients with head trauma.

Methods: In this study, 40 patients with head trauma and ageand sex-matched 40 healthy children were included. Nerve sheath diameter was measured by transorbital sonography.

Results: Diameter of the mean optic nerve sheath of the right and left eye of the patients were $0.408 \pm 0.064 \mathrm{~mm}$ and $0.417 \pm 0.065 \mathrm{~mm}$, respectively; both results were higher in patients than in controls. In the right eyes of the patients, the ONSD values had a negative correlation with Glasgow Coma Scale scores. There was a positive correlation between systolic and diastolic blood pressures and optic nerve sheath diameters of patients. Clinical status of the patients at admission and blood $\mathrm{pH}$ levels were associated with ONSD.

Conclusion: The result of our study indicated that ONSD measurement is a non-invasive technique and can be used easily to estimate increased intracranial pressure in pediatric emergency departments.

Keywords: Head trauma, optic nerve, intracranial pressure, sonography

\section{Öz}

Giriş: Optik sinir kılıf çapı (OSKÇ) ölçümü çocuklar ve yetişkinlerde kafa içi basınç ölçümü için kullanılan invazif olmayan kolay bir görüntüleme tekniğidir. Biz bu çalışmada kafa travması olan çocuk hastalarda bu amaçla OSKÇ ölçmeyi amaçladık.

Yöntemler: Bu çalışmada, kafa travmalı 40 hasta ve yaş ve cinsiyet açısından eşleştirilmiş 40 sağlıklı kontrol hasta çalışma kapsamına alındı. Sinir kılıfı çapı transorbital sonografik yöntem ile ölçüldü.

Bulgular: Hastaların ortalama OSKÇ sağ ve sol göz için sırasıyla

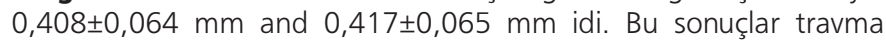
hastalarında kontrol grubundan daha yüksekti. Hastaların sağ göz OSKÇ değerleri Glaskow Koma Skalası skorları arasında negatif korelasyon vardı. Hastaların sistolik ve diastolik kan basınçları ile OSKÇ değerleri arasında pozitif bir korelasyon vardı. Hastanın başvuru sırasındaki klinik durumu ve kan $\mathrm{pH}$ düzeyleri de OSKÇ ile ilişkili bulundu.

Sonuç: Sonuçlarımız göstermiştir ki; OSKÇ ölçümü invazif olmayan ve çocuk acil servislerinde kolaylıkla yapılabilecek bir görüntüleme işlemidir ve kafa içi basınç artışını erken belirlemede bize yardımcı olabilir.

Anahtar Kelimeler: Kafa travması, optic sinir, intrakraniyal basınç, sonografi

\section{Introduction}

Head trauma is associated with secondary brain injury and is a strong predictor of neurologic deficit in children. Following the head trauma, increased intracranial pressure (ICP) is the most important risk factor contributing to poor outcome. ${ }^{1}$ Managing pediatric head trauma with elevated ICP in the acute setting can be challenging. Roughly 3.000 deaths, 50.000 hospitalisations, and 650.000 emergency department
(ED) visits per year in the United States can be attributed to traumatic brain injury, the leading cause of death and disability caused by trauma in children..$^{2-4}$

The gold-standard technique remains invasive monitoring of ICP, using microsensor devices placed within the brain parenchyma or transduced external ventricular drains. It provides valuable diagnostic information but has specific limitations, including the risk of infection and haemorrhage..$^{5-7}$

Address for Correspondence/Yazışma Adresi: Sabiha Şahin MD, Eskişehir Osmangazi University Faculty of Medicine, Department of Pediatric Emergency, Eskişehir, Turkey

Phone: +90222 2268833 E-mail: sabiha.sahin@mynet.com ORCID ID: orcid.org/0000-0003-0759-4158

Received/Geliș Tarihi: 19.11.2018 Accepted/Kabul Tarihi: 07.02.2019

${ }^{\circ}$ Copyright 2019 by Society of Pediatric Emergency and Intensive Care Medicine

Journal of Pediatric Emergency and Pediatric Intensive Care published by Galenos Yayınevi. 
Anatomically, the optic nerve is a part of the central nervous system, which is surrounded by the dura mater, the subarachnoid space, and cerebrospinal fluid; therefore, any change in ICP affects the perioptic nerve sheath, changing its diameter. After the closure of the fontanelles, the optic nerve diameter and its sheath can be easily assessed by transorbital sonography. ${ }^{8-12}$

Application of emergency ultrasonography usage has expanded in the practice of emergency medicine. Bedside ocular ultrasound for measuring optic nerve sheath diameters (ONSDs) has been proposed as a portable, noninvasive method to detect increased ICP in ED patients with head trauma rapidly. The sonographic measurement of the optic nerve sheath diameter (ONSD) is sensitive, reliable, reproducible technic to measure ICP indirectly. ${ }^{13,14}$ Increased ONSD values have been reported in different disorders, and higher sensitivity and specificity rates were found in these studies. ${ }^{15,16}$ It has also been used to evaluate the effectiveness of treatment modalities in neurological diseases. ${ }^{17}$

In the present study, it was aimed to evaluate the ONSD values in children presenting to a pediatric ED with head trauma.

\section{Materials and Methods}

In this prospective study, 40 patients presenting to a pediatric ED with head trauma aged between 0 and 18 years were included between January 2015 and June 2015. All patients presenting with head trauma regardless of reason were invited to participate in the study. Forty healthy children matched with age and sex were enrolled as a control group. Children with any chronical disorder, haemorrhage, coagulopathy, ocular trauma, facial trauma, optic nerve disease, unstable vital signs, or need for urgent neurosurgical intervention were excluded. All parents or caregivers were informed about the study protocol, and written consent was obtained.

All children received standard medical management, including a complete physical examination and comprehensive neurologic examination. Examination results and the Glasgow Coma Scale (GCS) scores were recorded, and blood samples were obtained at admission. Also, all patients presenting with head trauma received neurological imaging.

Transorbital sonography with GE Vivid e portable sonography system (GE, USA) with a 5.0-to-13.0-MHz 12L-RS wideband linear pediatric probe was performed by an experienced pediatric emergency physician trained in sonography. The probe was applied with water-soluble ultrasound gel to the closed eyelids and, if cooperative, the patients were asked to keep their eyes in the middle position. This provided an axial view of the orbit and optic nerve on transorbital sonography. Double individual measurements of the optic nerve diameter were performed $3 \mathrm{~mm}$ behind the globe in each eye, and the mean value was used as the optic nerve diameter for the statistical analysis.

This study was approved by Eskişehir Osmangazi University Ethics Committee (No:2015/80556824-10) and performed according to the principles of Helsinki Declaration.

\section{Statistical Analysis}

Statistical analysis was done using SPSS (Statistical Package for Social Sciences) for Windows 22.0 software. All data are expressed as mean, percentage and standard deviation with $95 \%$ confidence intervals $(95 \% \mathrm{Cls})$. The independent Student's t-test was used for comparing mean values, and the Wilcoxon sum rank test/Mann-Whitney test was used to compare median values. Statistical significance was set at $p<0.05$, and all significance testing was two-sided. Receiver operating characteristic (ROC) analysis was used for the diagnostic performance of BT for the prediction of increased ONSD. Based on ROC analysis, the best statistical cut-off value was calculated.

\section{Results}

During the study period, 40 patients and 40 controls were enrolled in the study. The case group consisted of 21 boys (52.5\%), and 19 girls (47.5\%) and the control group consisted of 23 boys $(57.5 \%)$ and 17 girls $(42.5 \%)$. The mean \pm SD age in the case group was $8.75 \pm 5.40$ years (range, 0 to 18 years) and that in the control group was $7.15 \pm 5.33$ years (range 0 , to 18 years); age and gender were not significantly different between the groups $(p=0.464$ for age and $p=0.411$ for gender).

In patients, the mean ONSD of right and left eyes were $0.408 \pm 0.064 \mathrm{~mm}$ and $0.417 \pm 0.065 \mathrm{~mm}$, respectively. In controls, the mean ONSD of right and left eyes were $0.353 \pm 0.042$ and $0.362 \pm 0.044 \mathrm{~mm}$, respectively. The mean ONSDs were significantly higher in patients than controls $(p<0.005)$ (Table 1).

Post-hoc analysis showed that the ONSD values of both eyes were increasing by age only in the control group $(p<0.05)$. However, there was no statistically significant association between ONSD and age in patients (Table 2).

The mean GCS score at admission was $13.40 \pm 3.02$ in patients. It was found that only in the right eyes of patients, the ONSD

Table 1. The mean optic nerve sheath diameters of patients and controls

\begin{tabular}{|lllllll|}
\hline \multirow{2}{*}{ Groups } & \multicolumn{2}{c}{ Patients $(\mathbf{n = 4 0})$} & \multicolumn{2}{c}{ Controls $(\mathbf{n}=\mathbf{4 0})$} & \multirow{2}{*}{ * } & p \\
& Mean & SD & Mean & SD & & \\
Right eye & 0.408 & 0.064 & 0.353 & 0.042 & 4.520 & $\geq 0.001$ \\
Left eye & 0.417 & 0.065 & 0.362 & 0.044 & 4.425 & $\geq 0.001$ \\
*Two sample Student t-test results, SD: Standard deviation & & \\
\hline
\end{tabular}


values were inversely associated with GCS score $(p<0.05)$ ONSD values increased as the GCS score decreased (Figure 1).

The mean systolic and diastolic blood pressures were $101.9 \pm 11.5 \mathrm{mmHg}$ and $65.3 \pm 6.7 \mathrm{mmHg}$ in patients and $105.6 \pm 20.3$ and $65.2 \pm 11.1 \mathrm{mmHg}$ in the control group, respectively. Analysis showed that in both eyes, there was a positive correlation between ONSD and arterial blood pressures in patients.

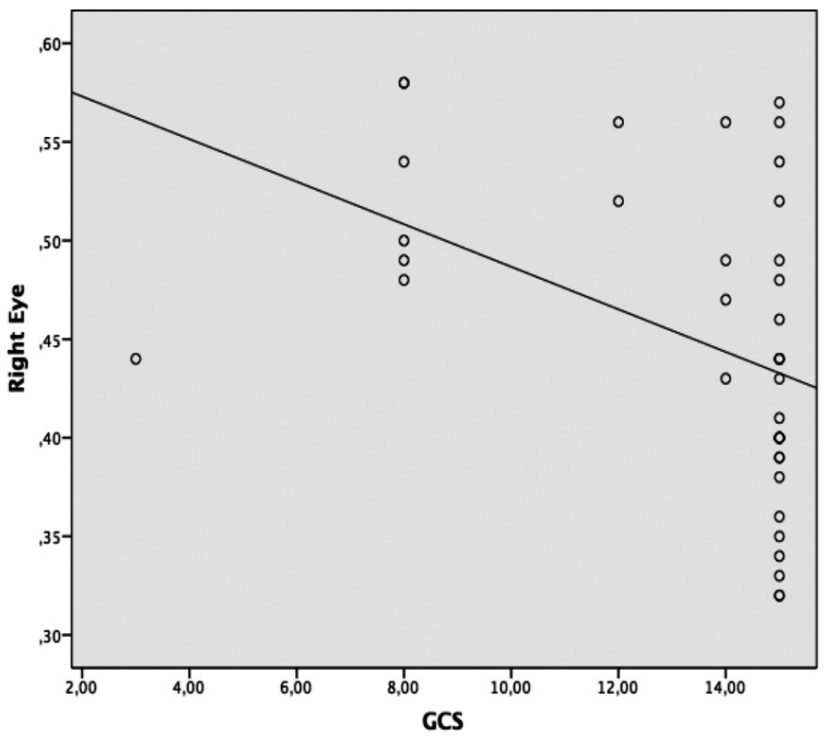

Figure 1. The relationship between Glasgow Coma Scale and optic nerve sheath diameter

GCS: Glasgow Coma Scale

Table 2. The relation of mean optic nerve sheath diameter and age of patients and controls

\begin{tabular}{|c|c|c|c|c|c|}
\hline Patients & Age group & $\mathbf{n}$ & mean & \pm SD & p \\
\hline \multirow{4}{*}{ Right eye } & $0-2$ & 8 & 0.408 & 0.095 & \multirow{4}{*}{0.408} \\
\hline & $3-6$ & 8 & 0.384 & 0.046 & \\
\hline & $7-12$ & 11 & 0.399 & 0.058 & \\
\hline & $13-18$ & 13 & 0.431 & 0.056 & \\
\hline \multirow{4}{*}{ Left eye } & $0-2$ & 8 & 0.413 & 0.100 & \multirow{4}{*}{0.410} \\
\hline & $3-6$ & 8 & 0.388 & 0.034 & \\
\hline & $7-12$ & 11 & 0.416 & 0.063 & \\
\hline & $13-18$ & 13 & 0.438 & 0.055 & \\
\hline Controls & Age group & $\mathrm{n}$ & mean & $\pm S D$ & $p$ \\
\hline \multirow{4}{*}{ Right eye } & $0-2$ & 8 & 0.305 & 0.025 & \multirow{4}{*}{$\geq 0.001$} \\
\hline & $3-6$ & 14 & 0.344 & 0.021 & \\
\hline & $7-12$ & 9 & 0.369 & 0.029 & \\
\hline & $13-18$ & 9 & 0.396 & 0.039 & \\
\hline \multirow{4}{*}{ Left eye } & $0-2$ & 8 & 0.309 & 0.031 & \multirow{4}{*}{$\geq 0.001$} \\
\hline & $3-6$ & 14 & 0.351 & 0.021 & \\
\hline & $7-12$ & 9 & 0.379 & 0.031 & \\
\hline & $13-18$ & 9 & 0.407 & 0.038 & \\
\hline
\end{tabular}

The arterial blood gas analysis showed that the mean blood $\mathrm{pH}$ value of patients was $7.37 \pm 0.11 \mathrm{mmol} / \mathrm{L}$. The statistical analysis revealed a negative correlation between $\mathrm{pH}$ value and ONSD in patients $(p<0.05)$.

At admission, presenting symptoms were irritability in 8 patients $(20.5 \%)$, neurological abnormality in $10(25 \%)$, loss of consciousness in $9(22.5 \%)$ and headache in $8(20.8 \%)$ in patients. When we evaluated the association between presenting symptoms and ONSDs, the mean ONSD values were significantly higher in patients with irritability, loss of consciousness and abnormal neurological findings $(p<0.05)$ (Table 3 ).

All patients received both computed tomography (CT) and MRI scanning. The presence of indicative signs of increased ICP on CT or MRI of the brain was assessed. The positive radiological finding was observed in $3(7.5 \%)$ patients by magnetic resonance imaging (MRI) and 11 (27.5\%) patients by computed CT. Positive radiological finding presence suggested ICP in CT but not in MRI correlated with increased ONSD $(p<0.05)$. Based on the ROC analysis, the cut-off value of ONSD for CT positivity was $0.481 \mathrm{~mm}$ for right eye and $0.464 \mathrm{~mm}$ for left eye (Figure 2).

Twenty-seven percent of patients $(n=11)$ were hospitalized and overall mortality rate was $10.0 \%(n=4)$. There was a significant relationship between mortality and ONSD $(p<0.005)$. (Table 4).

\section{Discussion}

Because of the relationship between the optic nerve sheath and cerebrospinal fluid, the diameter of optic nerve sheath

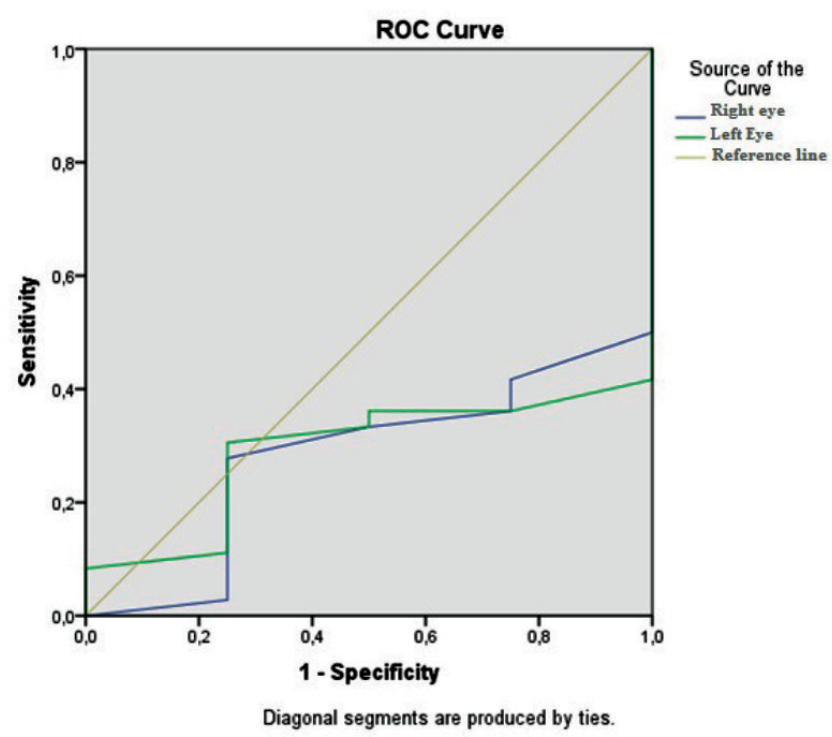

Figure 2. Receiver operating characteristic for computed tomography for the prediction of increased optic nerve sheath diameter in patients with head trauma

ROC: Receiver operating characteristic 
changes with alteration of the ICP. Optic nerve sheath diameter measurement has become a novel tool in the search for a rapid, noninvasive method of elevated ICP. The extracranial portion of the optic nerve, $20-30 \mathrm{~mm}$ in length, has an outer layer of dura mater, an arachnoid trabeculae space through which CSF circulates, and an inner layer comprising the arachnoid membrane. ONSD enlarges with an elevation of $I C P$, and these changes are present before the development of papilledema in the funduscopic examination. This method is a relatively simple bedside test within the scope of practice of emergency and critical care medicine. ${ }^{18-20}$

In our study, the mean ONSD values were significantly higher in patients with head trauma compared to healthy controls, and we found that ONSDs increased after head trauma. Our results indicate that increased value of ONSD suggested abnormal dilatation of optic nerve sheath and raised ICP may be suspected. We also examined the association between age and ONSD. We found no significant association between ONSD and age in the the patient group. But, post-hoc showed that the ONSD values of both eyes were increasing by age only in the control group. This may be result from the expansile structure of optic nerve sheath and its anatomic characteristics. ${ }^{15}$

Young et al. ${ }^{16}$ researched the correlation between optic nerve sheath diameter and ICP in pediatric traumatic brain injury. They revealed that the median right ONSD was $5.6 \pm 2.5 \mathrm{~mm}$ and the left was $5.9 \pm 3.2 \mathrm{~mm}$. Both ONSDs were significantly correlated with initial ICP and age of the patient was not a factor associated with ONSD. Padayachy et al. ${ }^{21}$ reported that ONSD was $6.28 \mathrm{~mm}$ in cases with increased intracranial

Table 3. The association between presenting symptom and optic nerve sheath diameter in patients

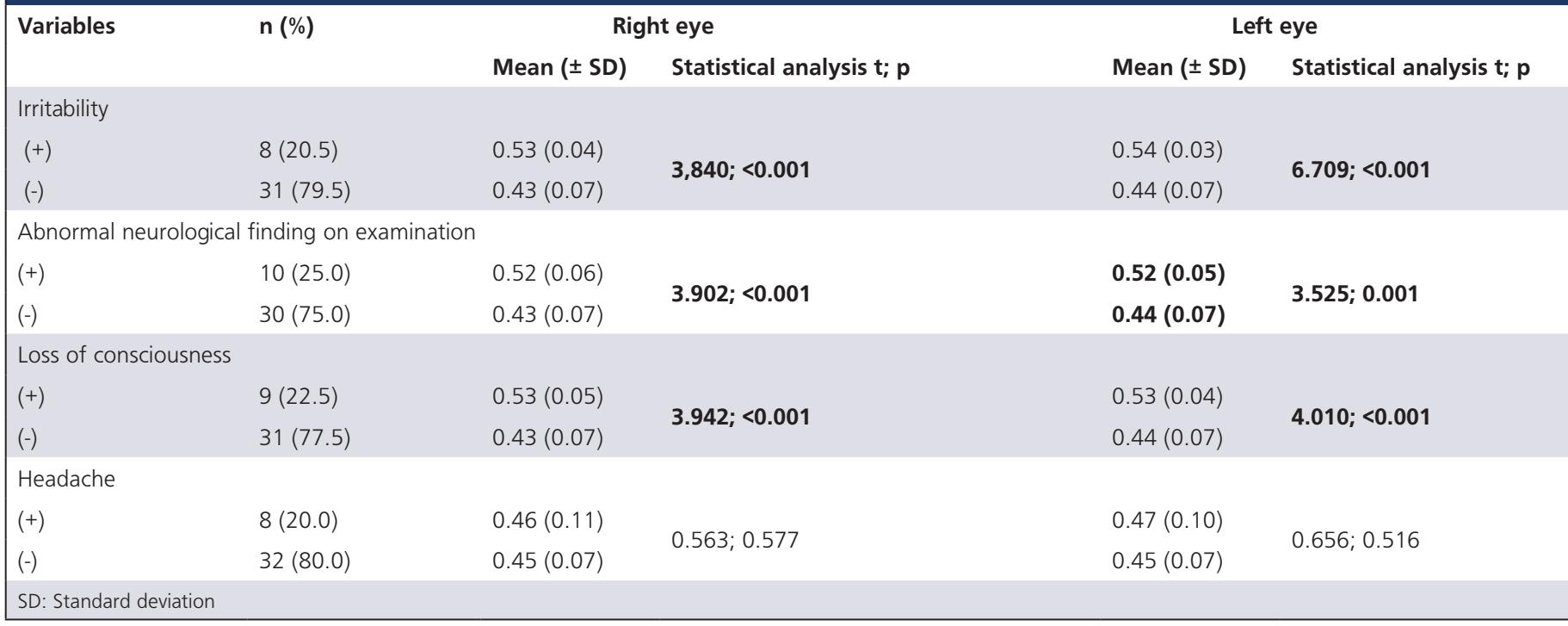

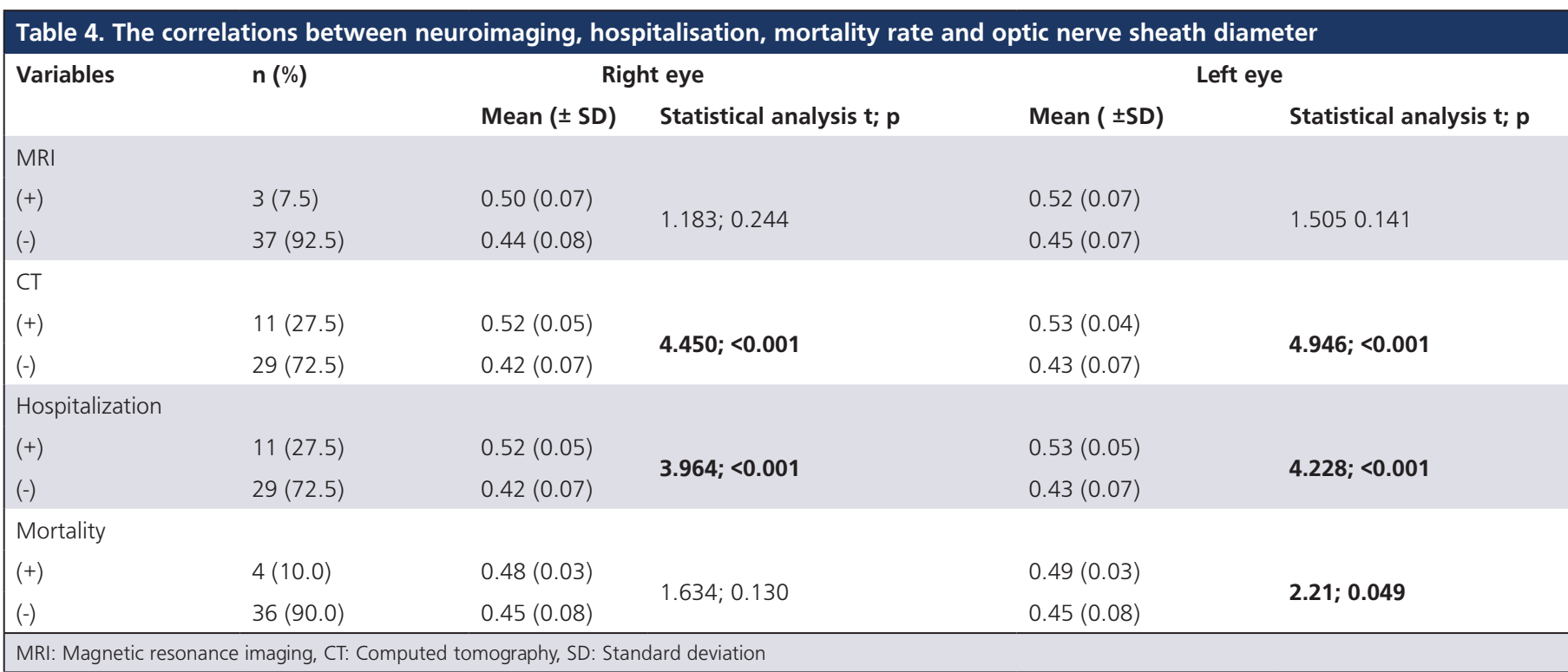


pressure. Our mean ONSD values were slightly lower than reported values. The severity of head trauma or ICP possibly affect the ONSD results.

Based on the literature, there are numerous factors that influence the prognosis of TBI patients, including gender, age, severity of injury, anticoagulant use, comorbids, arrival GCS, and the region of affected brain on CT scan. The International Mission for Prognosis and Analysis of Clinical Trials and the Corticosteroid Randomisation After Significant Head Injury Prognostic scores are not meant for the ED estimation for TBI severity.22 Optic nerve is suggested as the most easily accessible part of the brain meninges and there are studies demonstrating the effectiveness of the ONSD on CT scans with the ICP and the severity of the brain injury. ${ }^{23}$ In the present study, we found that only in the right eyes of patients, the ONSD values were inversely associated with GCS score. Right ONSD values increased as the GCS score decreased. The explanation of result is complicated but it may result from our small sample size.

The medical literature is agreed that CT must be the first choice of neuroimaging in case of head trauma. ${ }^{24} \mathrm{~A}$ meta-analysis assessing the accuracy of sonographic measurement of ONSD when compared with $\mathrm{CT}$ reported a sensitivity of $95.6 \%$ and a specificity of $92.3 \% .^{25}$ The results of our study showed that positive radiological finding on computerised CT scanning was correlated with increased ONSD. Also, measurement of ONSDs may be used to screen patients for elevated ICP before the performance of invasive ICP measurement methods such as lumbar puncture and may obviate the need for $C T$ and MRI scan of the head in the otherwise neurologically normal patient. Advantages of ocular ultrasound over CT and MRI are its portability, availability to the ED physician, steep learning curve, relatively low cost, and lack of exposure to ionising radiation.

\section{Study Limitations}

The main limitation of our study is relatively small sample size. Also, we did not measure intracranial pressure with goldstandard methods. Therefore, we could not directly evaluate the relation between ONSD and ICP values. Further studies are required to determine its clinical value for determination of raised ICP in patients with head trauma.

\section{Conclusion}

Numerous condition associated with elevated ICP in the pediatric population, such as head trauma, brain tumours, cerebral edema in diabetic ketoacidosis, malfunctioning ventriculoperitoneal shunts for hydrocephalus, and pseudotumor cerebri, can be expected to present to the pediatric Ehlers-Danlos syndromes (EDs). Rapid and noninvasive detection of elevated ICP would be valuable to facilitate treatment and care, especially if there are delays in obtaining definitive imaging such as CT. ONSD may be useful in the pediatric ED and other acute care settings to detect elevated ICP. Research in this technique as a diagnostic test is needed with large numbers of subjects to describe its test performance characteristics and to determine its clinical usefulness in a variety of acute conditions associated with elevated ICP in the emergent setting.

\section{Ethics}

Ethics Committee Approval: This study was approved by Eskişehir Osmangazi University Ethics Committee (No:2015/80556824-10) and performed according to the principles of Helsinki Declaration.

Informed Consent: All parents or caregivers were informed about the study protocol, and written consent was obtained.

Peer-review: Externally peer-reviewed.

\section{Authorship Contributions}

Surgical and Medical Practices: K.B.C., C.Y., S.Ş., Concept: S.Ş., C.Y., Design: S.Ş., Data Collection or Processing: S.Ş., Analysis or Interpretation: K.B.C., Literature Search: S.Ş., K.B.C., C.Y., Writing: S.Ş.

Conflict of Interest: The authors declared that there is no conflicting of interest.

Financial Disclosure: The authors declared that no funding was received.

\section{References}

1. Sarioglu FC, Sahin H, Pekcevik Y, Sarioglu O, Oztekin O. Pediatric head trauma: an extensive review on imaging requisites and unique imaging findings. Eur J Trauma Emerg Surg. 2018;44:351-68.

2. Centers for Disease Control and Prevention. 2000 National Hospital Ambulatory Medical Care Survey, Emergency Department File 2002. Hyattsville, Md. Adv Data. 2004;18:1-34.

3. Faul M, Xu L, Wald MM, Coronado VG. Traumatic Brain Injury in the United States: Emergency Department Visits, Hospitalizations and Deaths 2002-2006. Atlanta (GA): Centers for Disease Control and Prevention, National Center for Injury Prevention and Control; 2010:1-74

4. Tsung JW, Blaivas M, Cooper A, Levick NR. A rapid noninvasive method of detecting elevated intracranial pressure using bedside ocular ultrasound application to 3 cases of head trauma in the pediatric emergency department. Pediatr Emerg Care. 2005;21:94-8.

5. Czosnyka M, Pickard J. Monitoring and interpretation of intracranial pressure. J Neurol Neurosurg Psychiatry. 2004;75:813-21.

6. Wiegand C, Richards P. Measurement of intracranial pressure in children: a critical review of current methods. Develop Med Child Neurol. 2007;49:935-41.

7. Padayachy L, Figaji A, Bullock RS. Intracranial pressure monitoring for traumatic brain injury in the modern era. Childs Nerv Syst. 2010;26:441-52. 
8. Helmke K, Hansen HC. Fundamentals of transorbital sonographic evaluation of optic nerve sheath expansion under intracranial hypertension II: patient study. Pediatr Radiol. 1996;26:706-10.

9. Galetta S, Byrne SF, Smith JL. Echographic correlation of optic nerve sheath size and cerebrospinal fluid pressure. J Clin Neuroophthalmol. 1989;9:79-82.

10. Ballantyne J, Hollman AS, Hamilton R, Bradnam MS, Carachi R, et al. Transorbital optic nerve sheath ultrasonography in normal children. Clin Radiol. 1999;54:740-2.

11. Berhman RE, Voghan VC. Pediatric ophthalmology. In: Behrman RE, Kliegman RM, Arvin AM (eds). Nelson Textbook of Pediatrics. 13th ed. Philadelphia, PA: WB Saunders Co; 1998:1319-27.

12. Hewick SA, Fairhead AC, Culy JC, Atta HR. A comparison of 10 $\mathrm{MHz}$ and $20 \mathrm{MHz}$ ultrasound probes in imaging the eye and orbit. Br J Ophthalmol. 2004;88:551-5.

13. Helmke K, Hansen HC. Fundamentals of transorbital sonographic evaluation of optic nerve sheath expansion under intracranial hypertension II. Patient study. Pediatr Radiol. 1996;26:706-11.

14. Dubourg J, Javouhey E, Geeraerts T, Messerer M, Kassai B. Ultrasonography of optic nerve sheath diameter for detection of raised intracranial pressure: a systematic review and meta-analysis. Intensive Care Med. 2011:37:1059-68.

15. Malayeri AA, Bavarian S, Mehdizadeh M. Sonographic evaluation of optic nerve diameter in children with raised intracranial pressure. J Ultrasound Med. 2005;24:143-7

16. Young AM, Guilfoyle MR, Donnelly J, Scoffings D, Fernandes $H$, et al. Correlating optic nerve sheath diameter with opening intracranial pressure in pediatric traumatic brain injury. Pediatr Res. 2017;81:443-47.

17. Singhal A, Yang MM, Sargent MA, Cochrane DD. Does optic nerve sheath diameter on MRI decrease with clinically improved pediatric hydrocephalus? Childs Nerv Syst. 2013;29:269-74.
18. Irazuzta JE, Brown ME, Akhtar J. Bedside Optic Nerve Sheath Diameter Assessment in the Identification of Increased Intracranial Pressure in Suspected Idiopathic Intracranial Hypertension. Pediatr Neurol. 2016;54:35-8.

19. Newman WD, Hollman AS, Dutton GN, Carachi R. Measurement of optic nerve sheath diameter by ultrasound: a means of detecting acute raised intracranial pressure in hydrocephalus. $\mathrm{Br} J$ Ophthalmol. 2002;86:1109-13.

20. Marchese RF, Mistry RD, Binenbaum G, Liu GT, Scarfone RJ, et al. Identification of Optic Nerve Swelling Using Point-of-Care Ocular Ultrasound in Children. Pediatr Emerg Care. 2018;34:531-6.

21. Padayachy LC, Padayachy $V$, Galal U, Gray R, Fieggen AG. The relationship between transorbital ultrasound measurement of the optic nerve sheath diameter (ONSD) and invasively measured ICP in children: Part I: repeatability, observer variability and general analysis. Childs Nerv Syst. 2016;32:1769-78.

22. Steyerberg EW, Mushkudiani N, Perel P, Butcher I, Lu J, et al. Predicting outcome after traumatic brain injury: development and international validation of prognostic scores based on admission characteristics. PLoS Med. 2008;5:e165.

23. Geeraerts $T$, Launey $Y$, Martin L, Pottecher J, Vigué $B$, et al. Ultrasonography of the optic nerve sheath may be useful for detecting raised intracranial pressure after severe brain injury. Intensive Care Med. 2007;33:1704-11.

24. Useche JN, Bermudez S. Conventional Computed Tomography and Magnetic Resonance in Brain Concussion. Neuroimaging Clin N Am. 2018;28:15-29.

25. Ohle R, Mclsaac SM, Woo MY, Perry JJ. Sonography of the Optic Nerve Sheath Diameter for Detection of Raised Intracranial Pressure Compared to Computed Tomography: A Systematic Review and Meta-analysis. J Ultrasound Med. 2015;34:1285-94. 